\title{
Stratigraphic framework of the Apulian deep-water coral province, Ionian Sea
}

\author{
E. Malinvernoa, , M. Tavianib, A. Rossoc, D. Violantid, I. Villaa, A. Savinia, A. Vertinob, c, A. \\ Remiab, C. Corsellia \\ a ULR CoNISMa - Dipartimento di Scienze Geologiche e Geotecnologie, Milano-Bicocca \\ University, Piazza della Scienza, 4-20126 Milano, Italy \\ b ISMAR, CNR, Bologna, Via Gobetti, 101-40129 Bologna, Italy \\ c ULR CoNISMa - Dipartimento di Scienze Geologiche, Sezione di Oceanologia e Paleoecologia, \\ Catania University, Corso Italia, 55-95129 Catania, Italy \\ d Dipartimento di Scienze della Terra, Torino University, via Valperga Caluso, 35-10125 Torino, \\ Italy
}

Available online 1 September 2009.

http://dx.doi.org/10.1016/j.dsr2.2009.08.025, How to Cite or Link Using DOI

Cited by in Scopus (4)

Permissions \& Reprints

Abstract

Shallow sediment lithology and stratigraphy were investigated at selected areas off Santa Maria di Leuca (SML) on the Apulian margin between 350 and $1200 \mathrm{~m}$ water depth, in order to define the sea-bottom character on which coral mounds have developed. According to existing geophysical data and in-situ observations, deep coral growth in the SML area creates patches of colonies typically settled on hard substrates on the upper flanks and/or near the top of mound-like structures and elongated ridges.

The sedimentary stratigraphy is strongly influenced by the local topography, which is modeled by tectonic and geomorphological forcing: large-scale erosional features, slope failure and sediment mass accumulation are evident from seismic investigations. Additionally, sites of preferential sediment accumulation due to the action of bottom currents are identified. As a result, a complex sedimentary pattern characterizes this part of the Apulian margin, with strong lateral variability in sediment type and age. Although hemipelagic silty clay constitutes the main lithology, there are sites characterized by periodic accumulation of silt and fine sand and local re-deposition of coarse biogenic sand from the surrounding areas and from shallower depths. Excluding one site, where mid-Pleistocene sediments are brought very close to the bottom-surface due to wide-scale erosion, all collected sediments are late Pleistocene to Holocene in age and fall biostratigraphically within the Emiliania huxleyi acme nannofossil zone. Reworking, detected through nannofossil analysis, is common in most cores, excluding the ones taken from topographic highs, and is variable in extent from site to site and within the sediment column; it includes Cretaceous to Early Pleistocene species, suggesting provenance from extended successions or various stratigraphic levels, outcropping on the submerged Apulian margin or in adjacent land sections. Reworking is often associated with a high content of lithogenic particles and an increase in the coarser (silt) fraction.

Coral debris was collected at many stations, both at the sediment surface and within the stratigraphic sequence, with varying abundance in relation to proximity to the coral colonies. Radiometric dating and micropaleontological analyses at some sites allow us to propose a sequence of coral colonization phases.

\section{Keywords}

Deep-sea corals; Stratigraphy; Lophelia; Madrepora; Ionian Sea; Mediterranean Sea

1. Introduction

The living and sub-modern Madrepora-Lophelia coral mounds from Santa Maria di Leuca (SML) display a mosaic-like distribution across a wide sector of the Ionian margin of Apulia between 350 
and $1200 \mathrm{~m}$ depth (Mastrototaro et al., 2001; Savini et al., 2004, [Taviani et al., 2005b] and [Freiwald et al., 2009]; Savini et al., 2005; Savini and Corselli, 2010; Vertino et al., 2010).

The large-scale morphology of the investigated area (Fig. 1) is related to a strong tectonic control, with elongated fault scarps that delineate a step-like topography. Superimposed on this pattern is geomorphological evidence of superficial deformation, which includes broad slope erosion, sediment sliding, block tilting and collapse. Additionally, the evolution of this sector of the Apulian margin is complicated by bottom currents, resulting in sediment remodeling and drifting (Taviani et al., 2005a; Savini and Corselli, 2010).

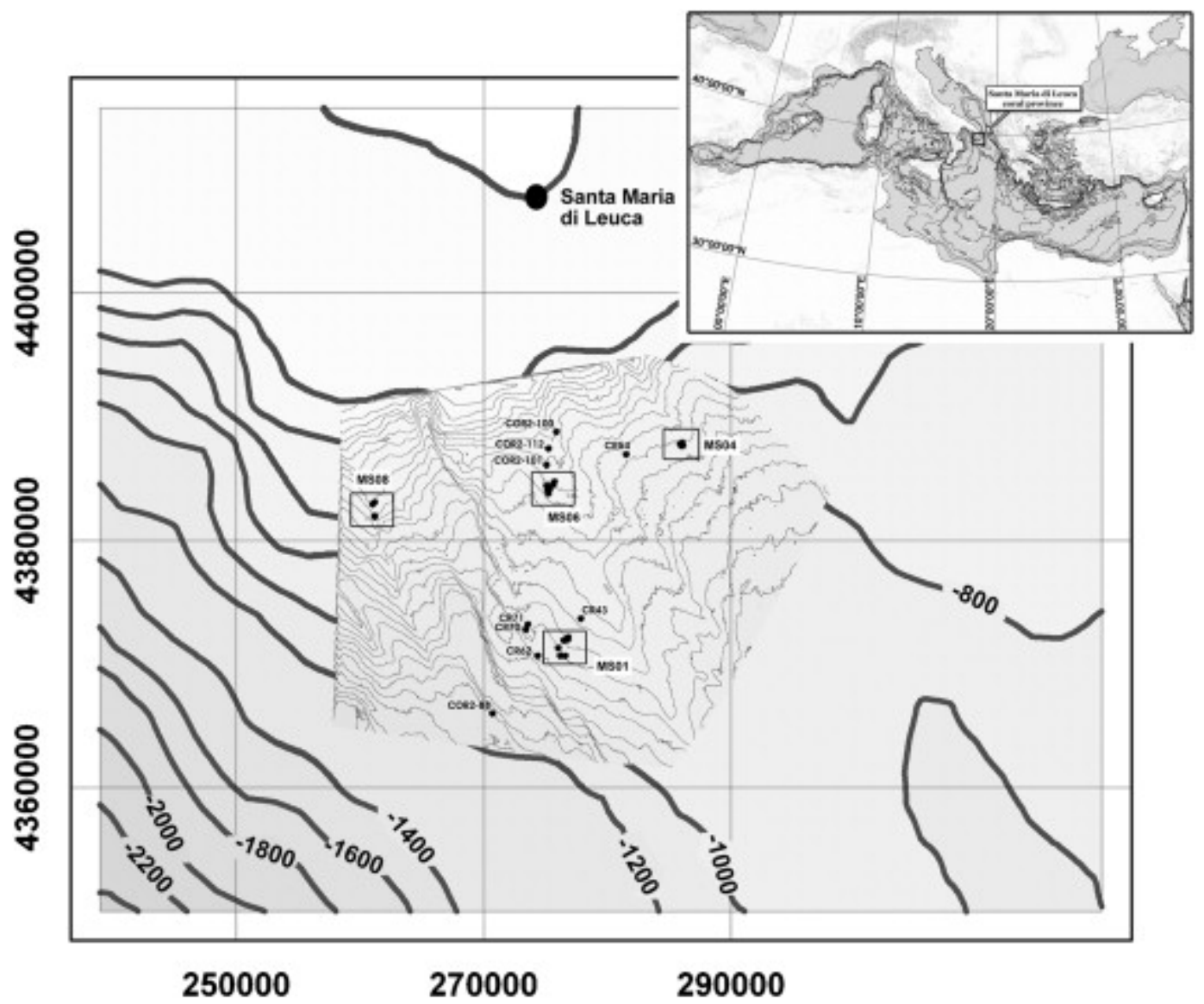

Fig. 1. General map of the study area; rectangles indicate the sub-areas where sampling was performed: the detailed morphology and sampling locations in these areas are shown in Figs. 2a, 5a, $7 \mathrm{a}$ and $9 \mathrm{a}$.

Deep-water corals colonize the sea bottom, forming thickets on discrete mounds and as isolated occurrences in inter-mound areas (Vertino et al., 2010). The only scant chronostratigraphic information on the area was provided by Taviani et al. (2005a) based upon gravity-cores and ingrab mini-cores. These preliminary data showed the common occurrence of late Pleistocene (Emiliania huxleyi acme nannofossil zone) units, exposed at the sea bottom or covered by a thin veneer of Holocene sediment, testifying a general low recent sedimentation rate and/or significant sweep by bottom currents. Evidence from epibenthic dredge sampling (Taviani et al., 2005b; Rosso et al., 2010; Vertino et al., 2010 and present dataset) have shown the co-occurrence of living corals with firm-ground blocks or hard-grounds, often embedding fragments of older corals.

The obvious need for more regional and detailed information called for further sampling in the coral mound area. This was achieved within the Aplabes project (Apulian PLAteau Bank Ecosystem Study, 2003-2006) by sea-bottom sampling through gravity and short-push cores during two dedicated cruises. Due to the geomorphological complexity of the area, a comprehensive 
sedimentological study would require an even wider sampling coverage. Instead, we focused our attention on selected sub-areas where previous surveys (Mastrototaro et al., 2001; Taviani et al., 2005a; Savini et al., 2004; Vertino et al., 2010) had shown a significant presence of coral colonies.

The scope of this article is twofold. Firstly the description of the main sedimentary and chronostratigraphic context of each selected area, with particular regard to the relation between the coral colonies and the bedrock. Secondly, a documentation of the early and subsequent phases of deep coral growth, based upon coral hard-grounds and buried pre-modern biostromal deposits.

2. Material and methods

2.1. Sediment samples

The material described in the present paper (Table 1) was collected during the following oceanographic cruises: Coral2 (R/V Urania, 2002; sample code COR2-), Aplabes3 (R/V Universitatis, 2005; sample code AP-) and Corsaro (R/V Urania, 2006; sample code CR-). Overall, 10 gravity-cores (GC) were collected, integrated by a series of mini-cores (GR) manually extracted from undisturbed large-volume (60-L) modified Van Veen grabs. Additional information was obtained from other grab samples and through dredge samples (DR), which collected the dominant lithology present at the (sub)surface along the dredge track and a modified Ingegno (see Taviani et al., 2005a), which allowed recovery of hard-ground and mud-buried coral fragments.

Table 1. Sample list, with location, water depth and core length.

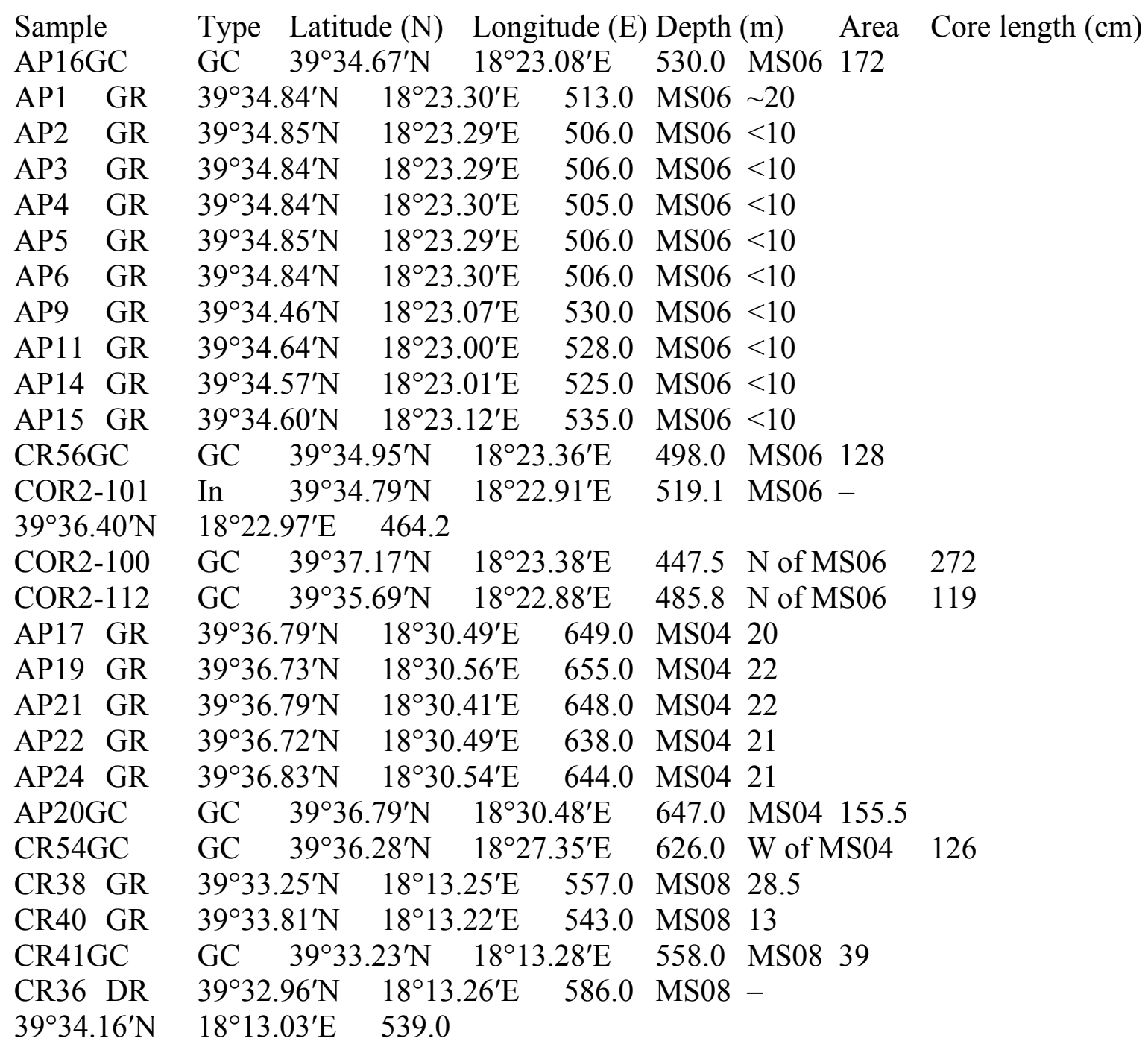




\begin{tabular}{|c|c|c|c|c|c|}
\hline AP28GC & $39^{\circ} 2$ & $.01{ }^{\prime} \mathrm{N}$ & $.18^{\prime} \mathrm{E}$ & $\begin{array}{lll}760.0 & \text { MS01 } 110.5\end{array}$ & \\
\hline AP30 GR & $39^{\circ} 28.09^{\prime} \mathrm{N}$ & $18^{\circ} 24.42^{\prime} \mathrm{E}$ & 747.0 & MS01 $\sim 10$ & \\
\hline CR58 GR & $39^{\circ} 28.15^{\prime} \mathrm{N}$ & $18^{\circ} 24.38^{\prime} \mathrm{E}$ & 745.0 & MS01 23 & \\
\hline CR43GC & $\mathrm{GC} \quad 39^{\circ} 2$ & $.98^{\prime} \mathrm{N} \quad 18^{\circ} 2$ & $.11^{\prime} \mathrm{E}$ & $702.0 \mathrm{NE}$ of $\mathrm{MS} 01$ & $77-5$ \\
\hline CR61 GR & $39^{\circ} 27.66^{\prime} \mathrm{N}$ & $18^{\circ} 23.85^{\prime} \mathrm{E}$ & 804.0 & MS01 17 & \\
\hline CR59 GR & $39^{\circ} 27.30^{\prime} \mathrm{N}$ & $18^{\circ} 23.96^{\prime} \mathrm{E}$ & 745.0 & SE of MS01 & \\
\hline CR60 GR & $39^{\circ} 27.32^{\prime} \mathrm{N}$ & $18^{\circ} 24.27^{\prime} \mathrm{E}$ & 793.0 & SE of MS01 17 & \\
\hline CR70 GR & $39^{\circ} 28.44^{\prime} \mathrm{N}$ & $18^{\circ} 21.98^{\prime} \mathrm{E}$ & 778.7 & NW of MS01 24 & \\
\hline CR71 GR & $39^{\circ} 28.67^{\prime} \mathrm{N}$ & $18^{\circ} 22.07^{\prime} \mathrm{E}$ & 783.2 & NW of MS01 11 & \\
\hline CR62 GR & $39^{\circ} 27.28^{\prime} \mathrm{N}$ & $18^{\circ} 22.71^{\prime} \mathrm{E}$ & 821.0 & SW of MS01 19 & \\
\hline COR2-88 & $\mathrm{GC} \quad 39^{\circ} 2$ & $.71^{\prime} \mathrm{N} \quad 18^{\circ} 2$ & $26^{\prime} \mathrm{E}$ & 1147.5 SW of MS01 & 134 \\
\hline
\end{tabular}

Sample locations (Fig. 1) were chosen to provide a substantial spatial coverage of the area settled by corals, although most sites were located off coral mounds proper, whose hard nature prevented grab and core penetration. Sub-areas were named by Savini and Corselli (2010), based on geophysical identification of coral-rich sites, selected for visual survey through a remote-controlled deep water vehicle (Vertino et al., 2010).

Gravity and mini-cores were opened, photographed and X-rayed on-shore. Descriptions refer to sediment nature, colors (Munsell soil chart), obvious sedimentary features and speditive analyses on macrofossil content. Cores AP20, COR2-88 and AP16 were investigated in more detail for grain size on selected sub-samples.

\subsection{Nannofossil biostratigraphy, micro- and macropaleontology}

Speditive biostratigraphic analyses were performed on calcareous nannoplankton assemblages at closely spaced $(5 \mathrm{~cm})$ core samples. A total of 151 samples were analyzed from all sediment cores. Samples were prepared following the standard smear slide technique (Perch-Nielsen, 1985). For each sample, approximately 300 specimens were counted through a polarized optical microscope at $1250 \times$. The biostratigraphic approach follows the biozonal scheme of Rio et al. (1990).

Sediment samples collected exclusively from site MS08 date to the early to middle Pleistocene (two samples from dredge CR36, belonging, respectively, to MNN19e and MNN19f, and the lower part of core CR41GC belonging to MNN19f). However, all other cores fall within the E. huxleyi acme zone (MNN 21b). According to the stratigraphic events described for the Eastern Mediterranean, the lower limit of this zone, defined by the stable frequency value of E. huxleyi above $20 \%$ on the total assemblage, is dated at 54 and $50 \mathrm{ky}$, between marine isotope stages 4 and 3 (i.e. Castradori, 1993; [Sprovieri et al., 1998] and [Lourens, 2004], respectively). As the lower zone boundary has never been reached in the investigated cores, accurate age assignment for all sections is not obtainable. However, quantitative estimate of E. huxleyi relative abundance within the nannofossil assemblage allows informal assignment to an "upper" or "lower" interval within the biozone (i.e. E. huxleyi above or below 50\%, respectively). This limit is roughly located within the Termination I interval (11.5-18 cal. ky B.P.), as resulting from the well-defined pattern of consistent downward E. huxleyi decrease observed within this time span (i.e. Castradori, 1993).

Macropaleontological assemblages were analyzed in selected sub-samples of cores AP20, COR2-88 and AP16, following the methods described in Rosso et al. (2010), in order to detect taxa indicative of peculiar environmental parameters and to recognize benthic thanatofacies (as defined in Rosso et al., 2010). The percentage volume of coral fragments was estimated from three representative depths at core AP20. 
Within the same core AP20, semi-quantitative estimates were made of planktonic (P) and benthic (B) foraminiferal relative abundances (i.e. abundant, common, few and rare) and of the $\mathrm{P} /(\mathrm{P}+\mathrm{B})$ ratio in the $>125-\mu \mathrm{m}$ fraction of 29 closely spaced (about $5 \mathrm{~cm}$ ) samples.

\subsection{Radiometric dating}

Three samples from the hard-ground and embedded corals from COR2-101 were dated through AMS 14C (Table 2). Dating was performed at the Poznan radiocarbon laboratory. Calibration of the AMS-ages was done with Calib Rev 5.0.1, using the Intcal04 surface marine calibration curve "marine04" of Hughen et al. (2004), with no reservoir age applied: calibrated age ranges are given in Table 2 within the $95.4 \%$ confidence intervals (2-sigma). One sample, dating back to $26,350 \pm 170$ y B.P., is beyond the marine calibration of Hughen et al. (2004).

Table 2. AMS 14C data.

Sample Lab-code Species State 14C-y B.P. 95.4\% range calBP Probability COR2-101A Poz-12687 Pseudamussium peslutrae Fossil 26,350 $170 \quad$ - Out of range

COR2-101B Poz-12688 Caryophyllia sp. Fossil 10,760 $\pm 50 \quad 12,562-12,515$ $2.2 \%$

$12,371-11,957 \quad 93.2 \%$

COR2-101C Poz-12689 Madrepora oculata Fossil 2975 $\pm 30 \quad 2825-2695 \quad 95.4 \%$

Two Lophelia fragments from core AP20 and one from grab AP30 were dated by U-Th disequilibrium using multicollector induction-coupled plasma mass spectrometry (Table 3 ). Analytical protocols followed Fleitmann et al. (2003). For the present study, the coral samples were mechanically divided into two fractions with a steel blade: the fine inner septa and the outer skeleton, labeled, respectively, S and A in Table 3. We observed that septa and outer skeleton incorporate very different $\mathrm{Th} / \mathrm{U}$ ratios: this makes it possible to accurately correct for detrital Th by an internal isochron using $\mathrm{A}$ and $\mathrm{S}$. Three-dimensional isochron fitting was performed using Isoplot/Ex (Ludwig, 1999).

Table 3. U-Th analyses. Ratios shown are activity ratios, and analytical uncertainties are given as one standard error (1 SE).

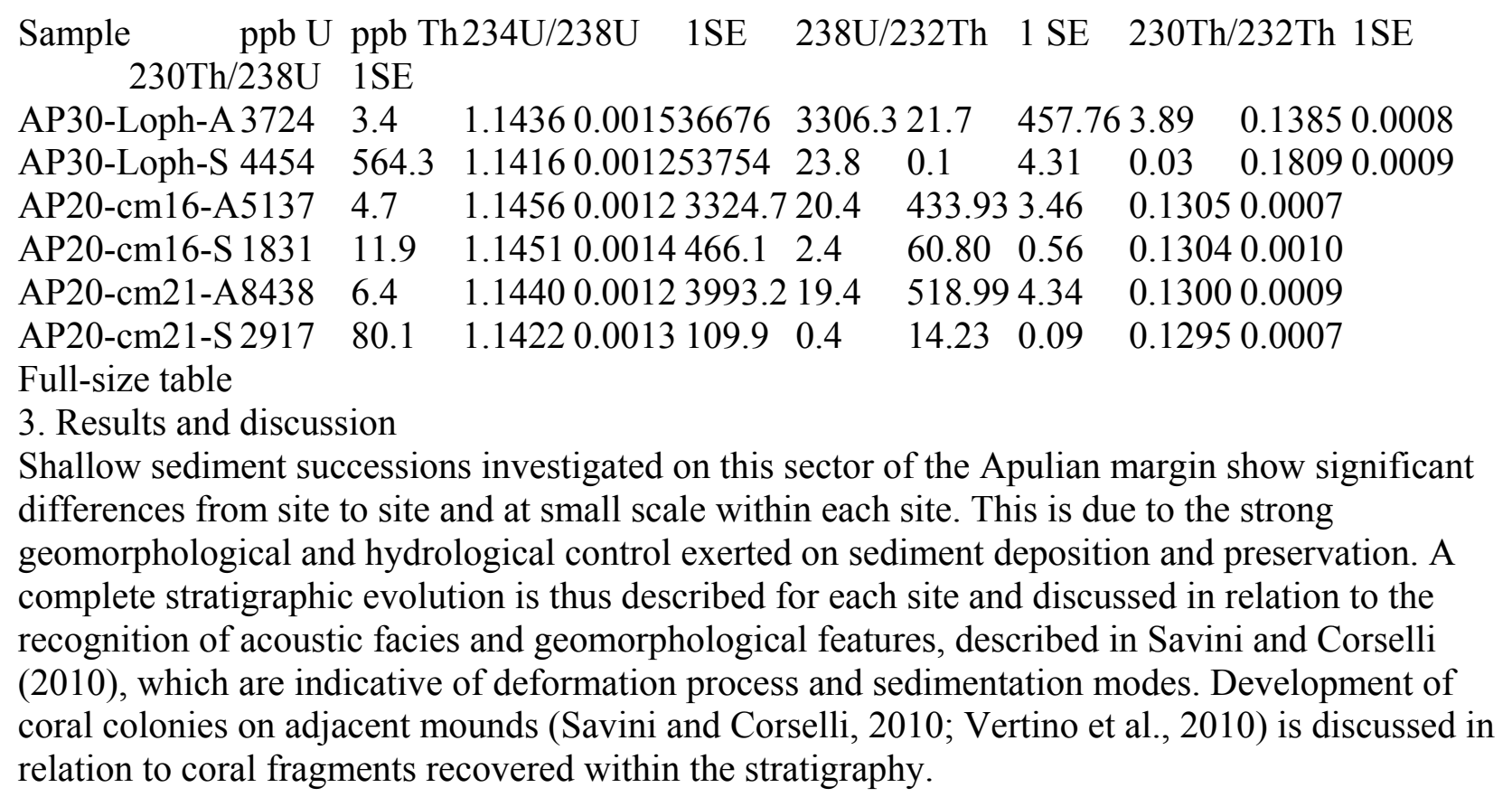


3.1. MS04 area - irregular mound-like topography, partly covered by a drape of sediments MS04 area is characterized by an irregular topography, acoustically characterized by uneven, overlapping hyperboles exposed at the seafloor or covered by a drape of sediments (echo-types III-1 and IV-1 of Savini and Corselli, 2010). Such morphology is interpreted as a result of intensive mass transport from the upper slope, with tilting and sliding of large blocks, resulting in mound-like morphologies. A subsequent cover of either hemipelagic, current-transported or massive sediments is present in some areas (Savini and Corselli, 2010).

Grabs were collected at different positions in the area (Fig. 2a), from the elevated structures to the rather flat zone at their base. Although restricted to the uppermost sediment sequence (all minicores fall within the upper part of the E. huxleyi zone), rather different lithologies were collected: from soft mud, largely consisting of silt and including fine sands (AP22, AP24), light olive brown in color, to muds containing a slightly coarser sandy, mostly bioclastic, fraction (soft and rich in pteropods, AP21, or stiff olive brown in color, with layers of fine sand, AP19). Only one core (AP17) recovered abundant fragments of dead corals (Madrepora, Lophelia, Desmophyllum), within a sandy mud sequence. Some grabs, planned to sample coral colonies on top of the large mound structure, failed to recover any sediment, probably due to the hard nature of the bottom. 

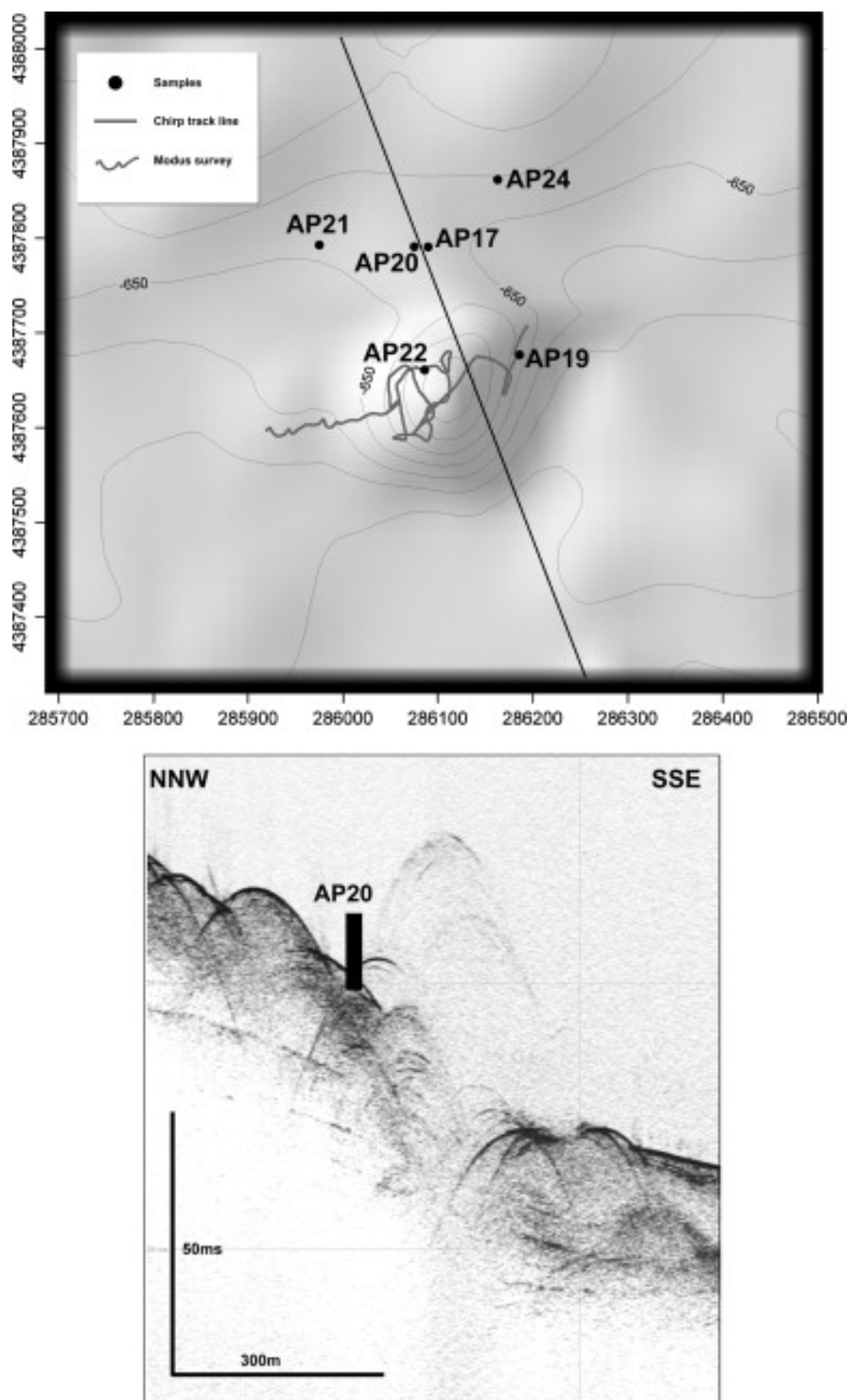

Fig. 2. (a) Map of MS04 area, with sampling location, track of the MODUS visual survey (Vertino et al., 2010) and track of chirp line shown in b; (b) chirp line across MS04 area, with the location of core AP20.

Gravity-core AP20 (155.5 cm) was collected within a rather flat (at the base of a slightly elevated) area (Fig. 2b) characterized by abundant coral rubble at the sediment surface and surrounded by extended areas where coral colonies are developed (Vertino et al., 2010).

The core consists of hemipelagic silts containing coral fragments at different intervals. Within the upper $30 \mathrm{~cm}$ the sediment is oxidized, light olive brown to light yellowish brown to grayish brown in color; all the rest of the core is gray to dark gray in color, with frequent black reduction spots, especially in the lower $30 \mathrm{~cm}$. The presence of abundant coral debris along the succession called for a more accurate investigation of the paleoenvironmental conditions of the area, with the aim to reconstruct the circumstances coinciding with the development of coral colonies and related production of coral debris. Core lithology, stratigraphy and paleoclimatic/paleoenvironmental data are summarized in Fig. 3. 


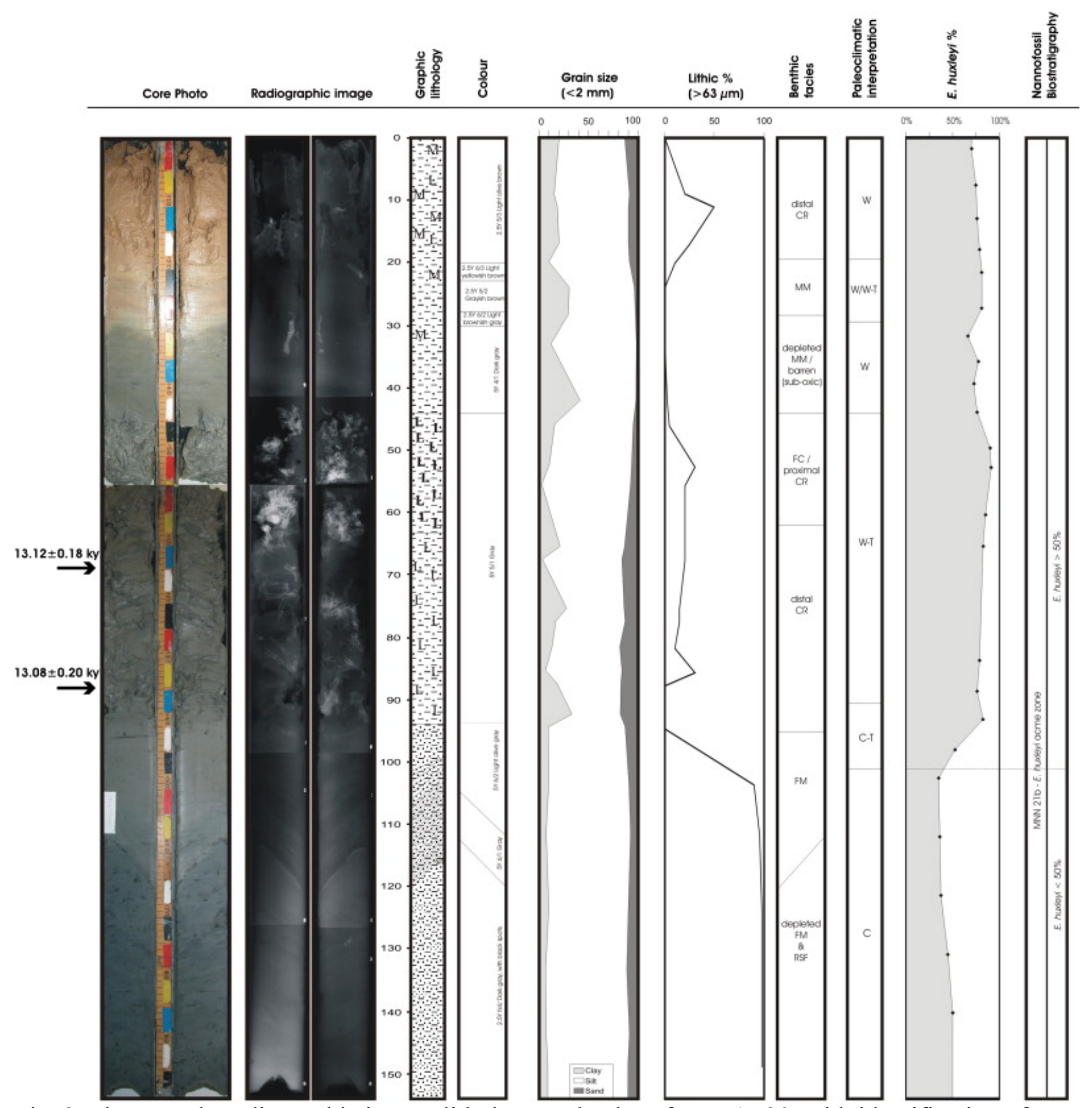

Fig. 3. Photograph, radiographic image, lithology and color of core AP20, with identification of bottom facies, paleoclimatic conditions, sedimentologic and (bio)stratigraphic characterization (see interpretation in Section 3.1 and legend from Fig. 6).

The upper part of the core (up to $97 \mathrm{~cm}$ ) consists of clayey to sandy silts, with intervals of gravelly silts characterized by a generally low abundance of lithogenic particles. Small coral fragments are sparse to abundant through the core. The upper $20 \mathrm{~cm}$ of the core contain sparse centimeter-sized Madrepora and subordinated smaller Lophelia fragments. These bioclasts show no preferential orientation and are unevenly distributed, reaching their maximum abundance between 11 and $17 \mathrm{~cm}$ (coral volume percentage around 10\%). Apart from rare fresh-looking fragments, corals are generally bio-eroded and covered by thin dark coatings, implying a relatively long exposure at the bottom-surface. One brown-coated Madrepora fragment was exposed at the surface when collected, as testified by encrusting live actinians. Other benthic faunas consist of a mixed assemblage of mostly in situ soft-bottom mollusk species associated with hard bottom species typical of framework coral (FC) and coral rubble (CR) facies (see Rosso et al., 2010). 
Encrusting foraminifera (Ammolagena clavata, Placopsilina bradyi, etc.) are common on biogenic fragments. In contrast to the upper part of this interval, showing a rather diversified benthic fauna, with foraminiferal taxa common in the epibathyal Mediterranean sediments (Cimerman and Langer, 1991; Sgarrella and Moncharmont Zei, 1993), samples from the 28.5- to 44-cm interval show a very depleted benthic fauna coupled with an extremely high content of planktonic foraminifera (ranging from $65 \%$ to $98 \%$ ) and a low-to-absent lithic content.

Corals become again significant from 44 to $97 \mathrm{~cm}$. Within the $44-64.5 \mathrm{~cm}$ interval, they create the main lithology (framework coral (FC) to proximal coral rubble (CR), as defined in Rosso et al., 2010), representing up to $40 \%$ of the sediment volume. Large fragments of Lophelia are here represented by thick-walled morphotypes (Fig. 4) that are closely packed and not or very little bioeroded, although usually partly colonized by serpulids and subordinate bryozoans, locally overcrusted by the corals. Some coral fragments clearly show to have been embedded in lithified mud (bioclastic limestone), the whole fragments being sometimes colonized by encrusting serpulids and bryozoans. In the $64.5-97 \mathrm{~cm}$ segment, corals are sparsely embedded in the muddy matrix (coral volume percentage around 15\%). Lophelia fragments, though less abundant, still dominate, exhibiting a thinner and more elongated trumpet-like morphotype (Fig. 3C in Rosso et al., 2009), according to the terminology by Freiwald et al. (1997).

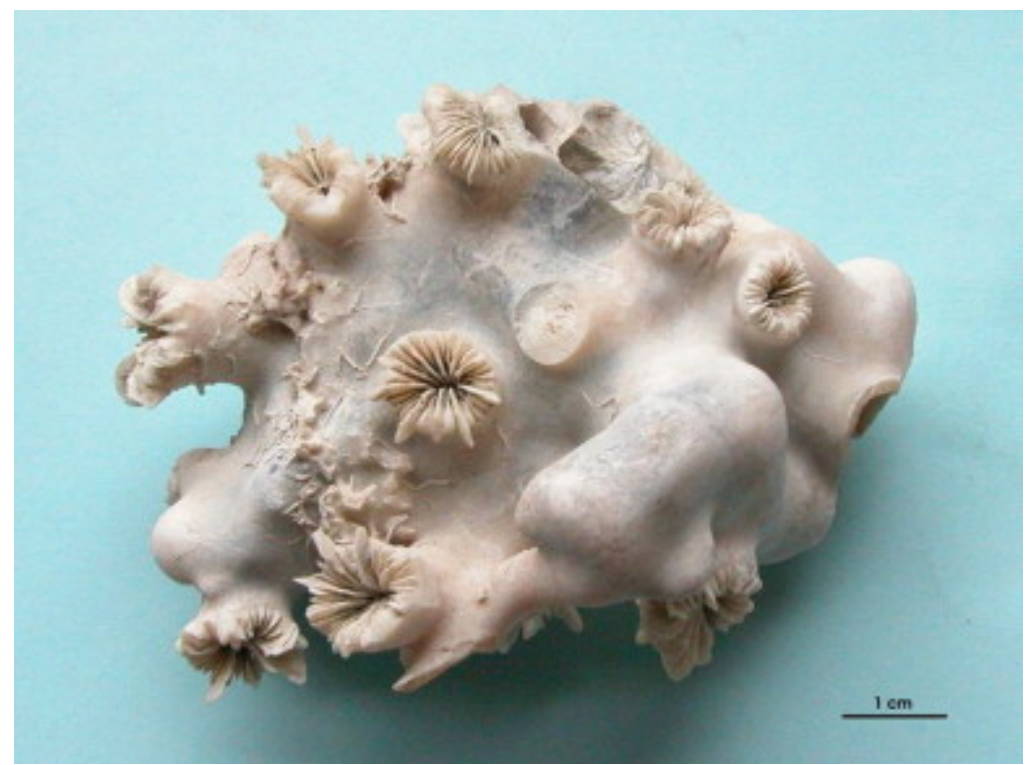

Fig. 4. Image of the thick-walled morphotype of Lophelia recovered in core AP20 (44-64.5 cm depth).

Within the entire coral-rich interval $(44-97 \mathrm{~cm})$, the associated benthic faunas are predominantly typical of hard bottom coral substrates, mostly including tubes of the serpulid Filograna, bryozoans and bivalves, such as anomiids, arcids and the pectinid Delectopecten vitreus. Soft-bottom-related faunas are also present, mainly represented by infaunal bivalves and carapaces of the crustacean decapod Ebalia nux, and by common benthic foraminifera, as Bulimina marginata. Huge rosalinids, probably or very close to Hyrrokkin sp., a parasite on present-day corals (Freiwald and Schönfeld, 1996) are also present. In this interval, the lithic content is absent to relatively abundant, but little reworking of planktonic flora (coccoliths) and fauna is evident.

The lower part of the core $(94.5-113.5 / 121.5 \mathrm{~cm})$ consists of sandy to clayey silts with an extremely high lithogenic content both in the coarse and fine fractions (90-95\% of the total). No coral debris is present in this part of the sequence and other benthic macrofaunas are extremely rare, with encrusting taxa completely lacking. Mollusks are only represented by few small-sized infaunal bivalves with isolated valves, usually belonging to juvenile specimens: Kelliella abyssicola and nuculoids have been recognized. More abundant planktonic and benthic foraminifera, mostly 
represented by Globorotalia inflata, B. marginata and Hyalinea balthica, point to a foraminiferal facies (FM, following the definition of Rosso et al., 2010), although the lithogenic content is very high. A distinct unconformity cuts the sediment sequence at an oblique angle at $113.5-121.5 \mathrm{~cm}$ and is marked by a thin (1 mm) layer of silt. Radiographic analysis (Fig. 3) reveals an interval with irregular lamination above the thin silt layer, lying at the same angle and becoming progressively horizontal upwards. Faint evidence of banding at oblique angles is also observed below the unconformity.

Below the unconformity, the basal interval consists of silts with subordinate clay content and frequent millimeter-thick coarser (silts with low percentages of fine sands) lenses. The sediments consist almost entirely of lithogenic material (98\%), in both the fine and coarse fractions. In samples from this interval, even the in situ microfaunistic assemblages become extremely rare, seemingly diluted by an increasing concentration of winnowed (displaced) specimens characterized by a significant input of shallow (coastal to shelf) foraminifera as Ammonia beccarii, Quinqueloculina spp. and Valvulineria bradyana (Murray, 2006); the planktonic components increasingly decline to values of less than $10 \%$.

Nannoplankton biostratigraphy allows us to place the whole core within the E. huxleyi acme zone. E. huxleyi is clearly dominant (relative abundance above 75-80\%) in the upper part of the core, then, from $100 \mathrm{~cm}$ to the bottom it decreases to values of 35-50\%. Therefore, this latter sector of the core lies below Marine Isotope Stage (MIS) 1, but well above the base of the E. huxleyi acme biozone (E. huxleyi values well above $20 \%$ ). U/Th dating performed on two coral specimens within the Lophelia-rich section (67.5-72.5 and $87.5-92.5 \mathrm{~cm}$, see Fig. 3), gave almost identical ages, respectively, $13.12 \pm 0.18$ and $13.08 \pm 0.20 \mathrm{ky}$, indicating fast deposition of this coral rubble interval, as also suggested by the good preservation and scarce-to-absent colonization and bio-erosion of the coral fragments.

Preliminary (micro) paleontological analyses using planktonic and benthic foraminifera allow us to infer warm to warm-temperate climates for the upper $44 \mathrm{~cm}$ of the core, where warm-water planktonic taxa, as Orbulina universa and Globigerinoides spp. (Hemleben et al., 1989), are dominant. Downward, a change from warm-temperate $(44-92.5 \mathrm{~cm})$ to cold-temperate waters $(92.5-103.5 \mathrm{~cm})$ is indicated by the increasing percentage of the temperate-water G. inflata (Hemleben et al., 1989; Pujol and Vergnaud Grazzini, 1995); the downward shift to cold conditions $(103.5-123 \mathrm{~cm})$ can be inferred from frequent cold-water planktonic taxa such as Neogloboquadrina pachyderma, Turborotalita quinqueloba (Kennett and Srinivasan, 1983) and abundant benthic H. balthica (Murray, 2006).

Within this broad frame, the dated Lophelia fragments fall within a temperate to warm-temperate interval, at the passage from Termination IA to the Younger Dryas, which occurs at approximately 13 cal. kyr B.P. Such dating confirms the (eco)biostratigraphic value of the E. huxleyi relative abundance decrease at the transition from MIS 1 to 2, and furthermore restricts this specific trend to the pre-Younger-Dryas interval.

The core records significant changes in benthic features, colonization and depositional history at the sampled site. The upper part of the core seemingly testifies to bottom conditions somewhat comparable to the present day, namely a coral mound location where sparse to closely spaced coral colonies, interspersed with a silty to muddy bottom, developed at different locations with time and not superimposing each other, thus not forming true build-ups. Consequently, the core likely records the subsequent existence of clayey silty bottoms with loose colonies (distal CR, with small Lophelia and/or Madrepora fragments and common to rare coral-associated faunas) in the top $20 \mathrm{~cm}$ to a gravelly silty bottom with closely-spaced colonies (proximal CR with large Lophelia fragments 
and common to rich coral-associated faunas) in the 44-94 cm interval. However, similar variations could also be caused by slight displacement events or by varying transport of coral debris from the colonized areas to the core sample site. The prominent scarcity of benthic faunas from the 28.5 to $44-\mathrm{cm}$ interval suggests dysoxic bottom conditions. This interval might represent a shallow analog to the pelagic S1 (9.5-6 uncorrected 14C ky B, e.g. Mercone et al., 2000), as also suggested by a short-term increase in Florisphaera profunda within the coccolith assemblages and by the temporal local abundance of warm-water foraminifera species and the concomitant reduction of warmtemperate species. Finally the basal part records substantial inputs of lithogenic and shallow carbonate material, transported from the shelf environment during an interval of cooler or colder conditions, located more close to the base of the E. huxleyi acme zone. Such interval can be related to mass transport (debris flow) during intervals of sea-level low-stand. The oblique surface observed in this interval suggests strong influence of (local) deformation processes, so that the sedimentary succession recovered at the bottom of the core likely represents the upper part of a slide block, whose sediments were tilted and plastically deformed, according to the geomorphological setting described by Savini and Corselli (2010), and subsequently covered by the hemipelagic sequence including coral rubble.

\subsection{MS06 area - irregular mound-like topography, scarcely covered by a drape of sediment} The area is characterized by the presence of intense large-scale deformation features, which result in an irregular bottom topography, displaying an acoustic facies characterized by hummocky topography, exposed at the seafloor or covered by a drape of sediments (echo-types III-1 and IV-1 of Savini and Corselli, 2010). It consists of a series of elevated structures, mostly elongated in a NNW-SSE direction. These are mainly related to the downslope failure of sediment blocks due to slides and/or rotational slumps, which cause intense sediment deformation (Savini and Corselli, 2010). Tilted blocks as well as exposed tilted strata have been observed from video-surveys (Vertino et al., 2010). These structures are colonised by abundant coral colonies, often represented by dead Mn-encrusted branches, which form the substratum for recent corals. They are separated by areas with prevalent mud cover.

Living coral colonies were collected at one site (AP01, Fig. 5a) on top of an elevated structure. They were large sized with the exposed skeleton of the near base branches densely colonized by encrusters and partly coated by dark crusts (Figs. 3 and 4 in Rosso et al., 2010). Recent hemipelagic silt was entrapped (baffled) within coral branches, hosting relatively impoverished soft-bottomrelated assemblages. U/Th dating of a fragment of Lophelia at the base of the sample gave an age of $13.96 \pm 0.18 \mathrm{ka}$. Other sampling from the same site (Fig. 5a) either was unsuccessful due to the hard nature of the bottom or obtained thin-layered slab-like hard-ground fragments (AP04) colonized by living actinians and other small-sized encrusting organisms (Fig. 14A-C; I-K in Rosso et al., 2010) or recovered only little quantity of sediment, mostly silt, locally including subordinate very fine sand (AP02, AP06), seemingly colonized only by microfauna assemblages (foraminifer mud (FM) facies of Rosso et al., 2010). The two longer sequences collected in MS06 area (gravity-cores) recovered rather different stratigraphic sequences (Fig. 6), due to the strong lateral variability of the geomorphological features and consequent small-scale local change of the deposits (Savini and Corselli, 2010). AP16 was collected within a depression between two elevated structures (Fig. 5b), while CR56 almost at the top of another elevated structure, ENE of the former. 

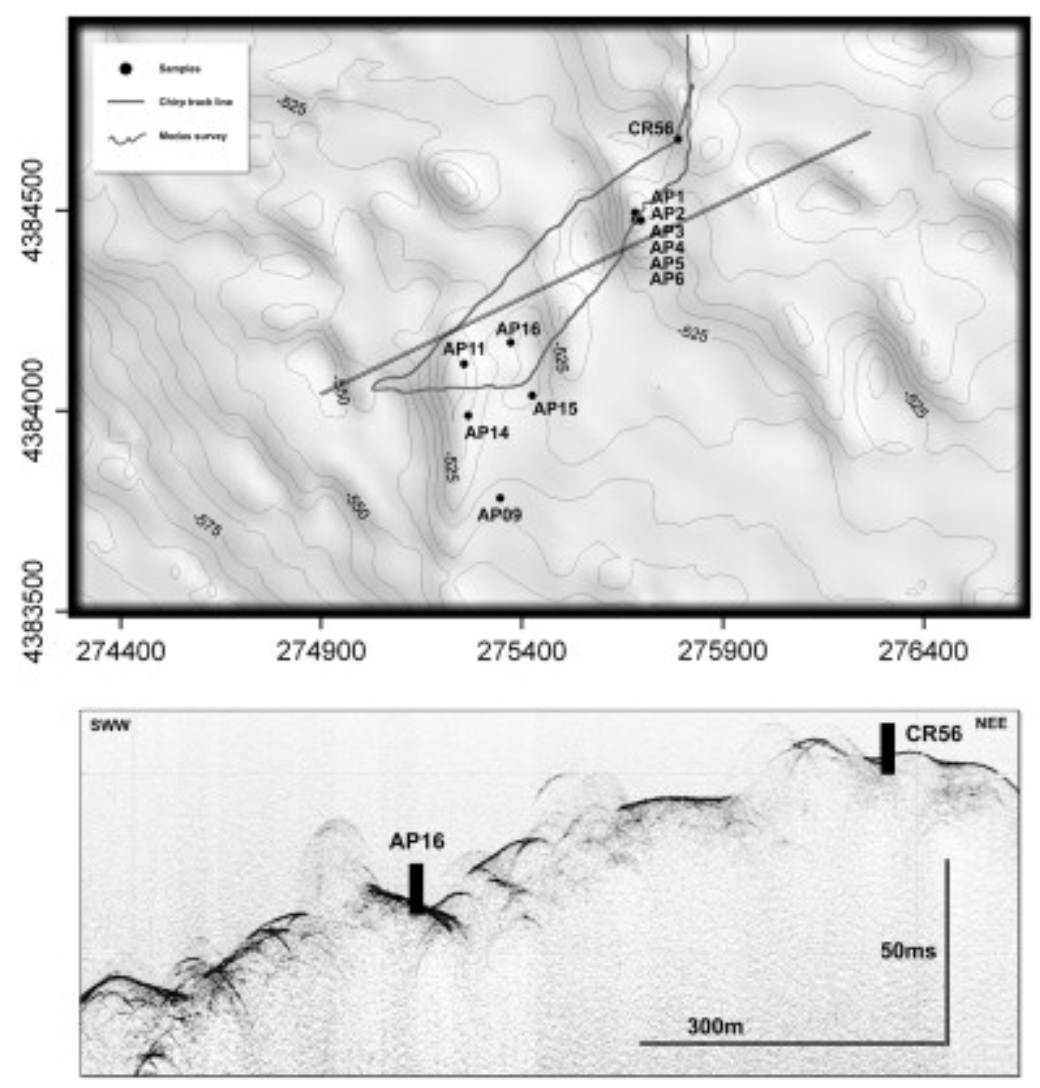

Fig. 5. (a) Map of MS06 area, with sampling location, track of the MODUS visual survey (Vertino et al., 2009) and track of chirp line shown in b; (b) chirp line across MS06 area, with the location of the two investigated cores.

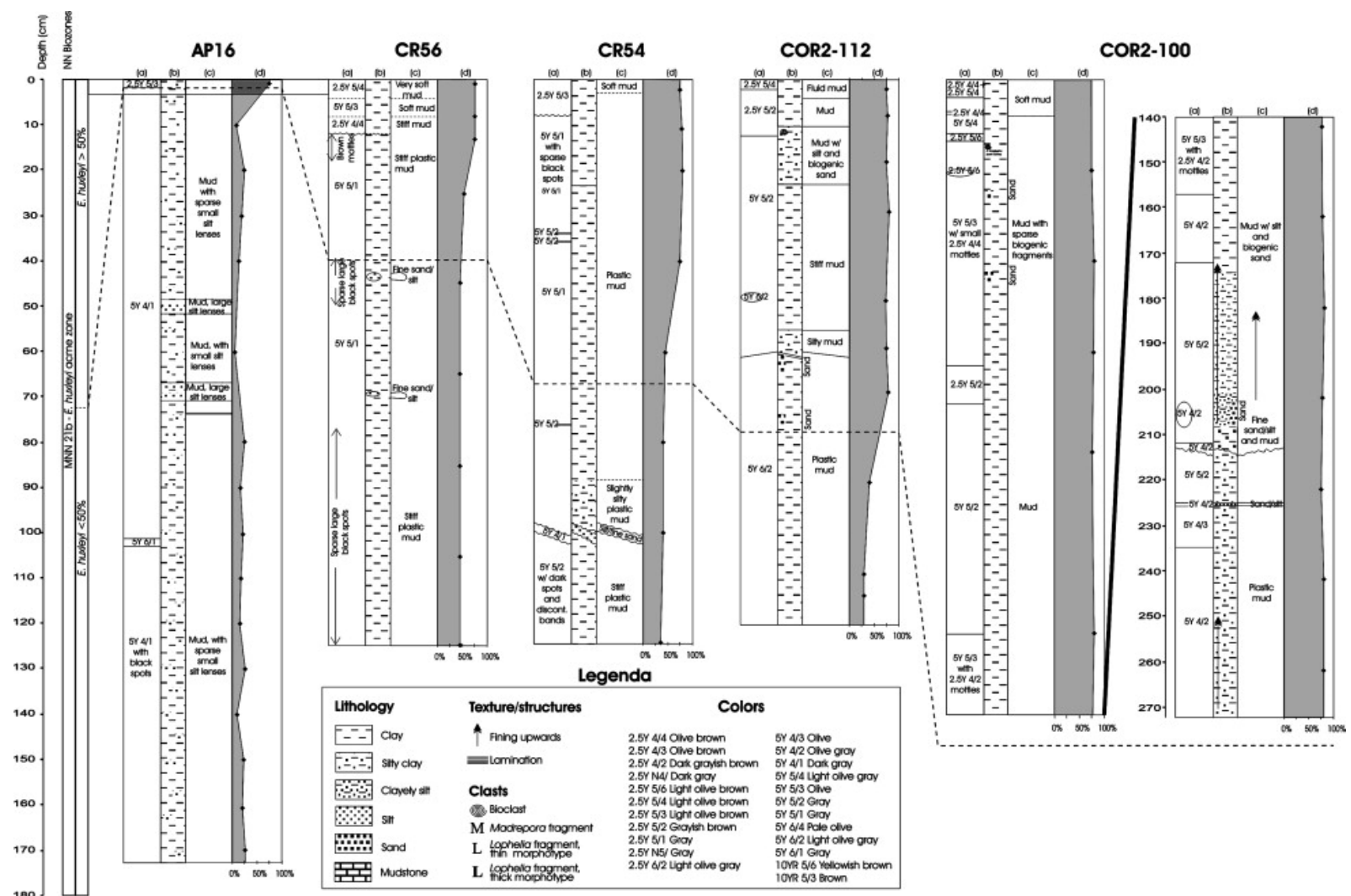

Fig. 6. Lithology of the cores collected within the MS06 area. For each core, four columns are shown, displaying (a) color, (b) graphic lithology, (c) sediment characterization, (d) relative abundance of E. huxleyi. 
Core AP16 $(172 \mathrm{~cm})$ consists of hemipelagic muddy silt (silt fraction $>70-75 \%$ ), with frequent mmthick coarser lenses. Only the upper $1 \mathrm{~cm}$ of the core is oxidized, light olive brown in color, while all the rest of the sediment is reduced, dark gray (5Y 4/1). Radiographic images of the core (not shown) indicate the presence of burrows in the upper $5 \mathrm{~cm}$, while irregular laminations are visible within certain portions of the sedimentary succession, given by the presence of the relatively coarser lenses within the sequence.

Excluding the upper few $\mathrm{cm}$, lithogenic particles are the main component of the sediment sequence, comprising at times the whole lithology, both in the coarser $(>63 \mu \mathrm{m})$ and in the fine fraction. Within the residues, plankton is extremely scarce as well as benthic assemblages, consisting of single foraminifer, ostracod and bivalve specimens. Most skeletons represent juveniles of shelfdwelling species, clearly displaced from shallower environments. Reworked nannofossil specimens (from Cretaceous to late Pleistocene in age) are abundant throughout the entire subsurface sequence. Although no erosional contact or unconformity is evident through visual observation or radiographic image, nannofossil biostratigraphic analyses reveal an upper layer $(10 \mathrm{~cm})$ of recent to sub-recent sediment, showing little or no reworking, lying on a sequence of sediments that were deposited close to the base of the E. huxleyi acme zone (E. huxleyi relative abundance from $15 \%$ to $30 \%)$.

Core CR56 $(128 \mathrm{~cm})$ is constituted by slightly silty clay, from very soft on top to stiff and plastic towards the bottom. The upper part of the core down to $14 \mathrm{~cm}$ is oxidized, light olive brown in color, with cm-thick olive to olive gray bandings; the rest of the core is reduced, homogenously gray in color, with brown mottles close to the oxidation front and abundant black spots in the lower part (around 43-52 cm and below $67 \mathrm{~cm}$ ). The oxidation front is irregular in shape, undulated, and is overlaid by an olive brown band, containing black reduction spots. Two cm-thick lenses of silt/fine sand (46 and $73 \mathrm{~cm}$ ) are present within the otherwise homogeneous plastic mud sequence. Fine grained lithogenic particles are scarce in the upper part, then rather abundant throughout the core.

Nannofossil biostratigraphic analyses place the entire sediment sequence within the upper part of the E. huxleyi acme zone (E. huxleyi from $>80 \%$ to $50 \%$ within the upper $50 \mathrm{~cm}$, then around $50 \%$ throughout all the rest of the core).

The two cores analyzed in this area thus reveal a different sediment history within a rather restricted area. The thin ( 1 to a few $\mathrm{cm}$ ) layer of recent hemipelagic mud grades into sub-recent silty clay, with frequent coarser (sand) input, in core CR56, while this interval is lacking in core AP16. The underlying sediment sequence (AP16) is represented by older gray clayey silt, which is similar in composition and floral-faunal content to that of the basal part of core AP20 (within MS04 area), although a biostratigraphic correlation cannot be drawn, as the lower boundary of the E. huxleyi acme zone was not reached in any of the cores. This latter sediment sequence likely represents displaced sediment, possibly related to former progradational units (strongly lithogenic mud, containing shelf fauna) re-deposited as massive deposits, and possibly in part influenced by the action of tractive currents (faint laminations), covered by a thin veneer of recent hemipelagic mud.

A very fortunate situation that has helped us understand the early phase of coral settlement at this site was the recovery of a large slab of hard-ground (COR2-101, from sampling through a modified ingegno) representing a condensed stratigraphy. The sample is a mudstone (firm-ground) entrapping disarticulated valves of the glacial Pleistocene pectinid Pseudamussium peslutrae lying parallel to each other. This taxon was a recurrent element of muddy shelf and slope assemblages in the Mediterranean Pleistocene up to the last glacial, as indicated by absolute dating at 20,000 \pm 1500 y B.P. (Malatesta and Zarlenga, 1986). Its presence within the mudstone is therefore consistent with 
its ecological requirements although its disarticulation is interpreted as resulting from the action of strong bottom currents. This hypothesis is also consistent with a number of samples in the SML coral province showing the widespread occurrence of loose, degraded and oriented P. peslutrae valves on the seafloor. An AMS 14C age of one P. peslutrae valve from COR2-101 gives a date of $26,350 \pm 170$ y B.P.

The first coral exploitation of the firm-ground is documented by Caryophyllia corallites, coated with $\mathrm{Mn}-\mathrm{Fe}$ oxides and dated at 10,760 \pm 50 y B.P. This early phase of coral growth was followed by a later colonising event as proven by non-coated Madrepora dated at 2,975 \pm 30 y B.P.

In synthesis, this hard-ground indicates a complex history that can be summarized as follows:

deposition of a Pleistocene muddy unit whose minimum age is represented by P. peslutrae

-

growth of P. peslutrae inhabiting the bottom during MIS3-2 (26,350 \pm 170 y B.P.)

onset of strong bottom currents responsible for bivalve orientation and sediment winnowing and somewhat prolonged non-depositional history at the site causing progressive induration of the sediment exposed to seawater and precipitation of $\mathrm{Fe}-\mathrm{Mn}$ oxides (firm-ground-hard-ground)

-

first colonization of the firm-ground by Caryophyllia (10,760 \pm 50 y B.P.)

-

death of Caryophyllia and prolonged non-depositional history, with dark coating of Caryophyllia corallites

$\bullet$

second (modern) phase of coral colonization by Madrepora (2,975 \pm 30 y B.P.)

3.3. Other areas from the upper slope - large mass-waste deposits, buried under a cover of mainly turbidite sedimentary units

Additional cores were collected within the SML area at selected spots (Fig. 1). CR54, collected in an area of possible coral growth (at MS04bis, coral mound structures and/or irregular topography were detected by chirp survey) recovered a sequence $(112 \mathrm{~cm})$ that is very similar to many other samples in the area, consisting of $10 \mathrm{~cm}$ of oxidized hemipelagic mud laying over a homogeneous gray stiff plastic mud, which becomes progressively more silty towards the base and contains a cmthick layer of fine sand $(101-103 \mathrm{~cm})$. The whole core lies within the upper part of the E. huxleyi zone. E. huxleyi is dominant from top to $46 \mathrm{~cm}$, then decreases slightly in abundance towards the bottom, to values lower than $50 \%$. Reworking is noted, though not common, throughout the core. Two other cores, COR2-100 and COR2-112, were collected north of MS06 site, in an area where no coral mound morphologies were identified. A sequence was recovered (respectively, 272 and 119 $\mathrm{cm}$ ) of hemipelagic clay with variable contribution of silt and periodic lenses and/or cm-thick layers of silt-fine sand, often showing an erosional contact. Although most of the sequence is homogenous, there are intervals showing faint lamination, possibly evidenced by lithological variability (more and less silty clay). The upper part of COR2-112 core belongs to the upper part of E. huxleyi acme zone. Below $74 \mathrm{~cm}$ E. huxleyi gradually decreases in abundance to $30 \%$ of the total assemblage. In contrast, the whole COR2-100 falls within the upper part of E. huxleyi acme zone. Reworking is slight in both cores but tends to increase in the lower part of COR2-112 core. These two cores were recovered in an area characterized by transparent acoustic facies, laying on eroded sedimentary layers (facies III-2 of Savini and Corselli, 2010). Such facies typically characterizes the upper slope (300-480 m depth) and is related to the recent cover of mixed hemipelagic and turbidite layers over previous massive slope-failure deposits (Savini and Corselli, 2010). A similar acoustic facies was described also for the area where CR54 was collected: here, mound-like structures, 
similar to those observed in MS04 and MS06 area, are partly buried under a cover of more or less massive sedimentary units that fill the topographic depressions (acoustic facies IV-1 of Savini and Corselli, 2010).

3.4. MS01 area - wavy topography, related to repeated massive deposition (debris and/or turbidite systems) by the influence of bottom currents

This deep area (Fig. 1 and Fig. 7a) is characterized by the presence of extensive NW-SE-trending fault scarps that delineate a large-scale step topography, with elongated highs. It is bordered to the NE by a large sediment ridge (drift deposit of Savini and Corselli, 2010). On a smaller scale, the entire area presents a rough topography (Fig. 7b), characterized by an acoustic response given by irregular waves and a moderate to strong semi-prolonged echo surface reflector, few meters thick and bounded below by eroded continuous sedimentary layers, with no or few internal reflectors indicating the dominance of coarse-grained sediments at the surface (facies IV-3 of Savini and Corselli, 2010). Widespread and scattered small hyperboles at the surface indicate the patches of coral colonies, whose presence was also confirmed through visual survey.
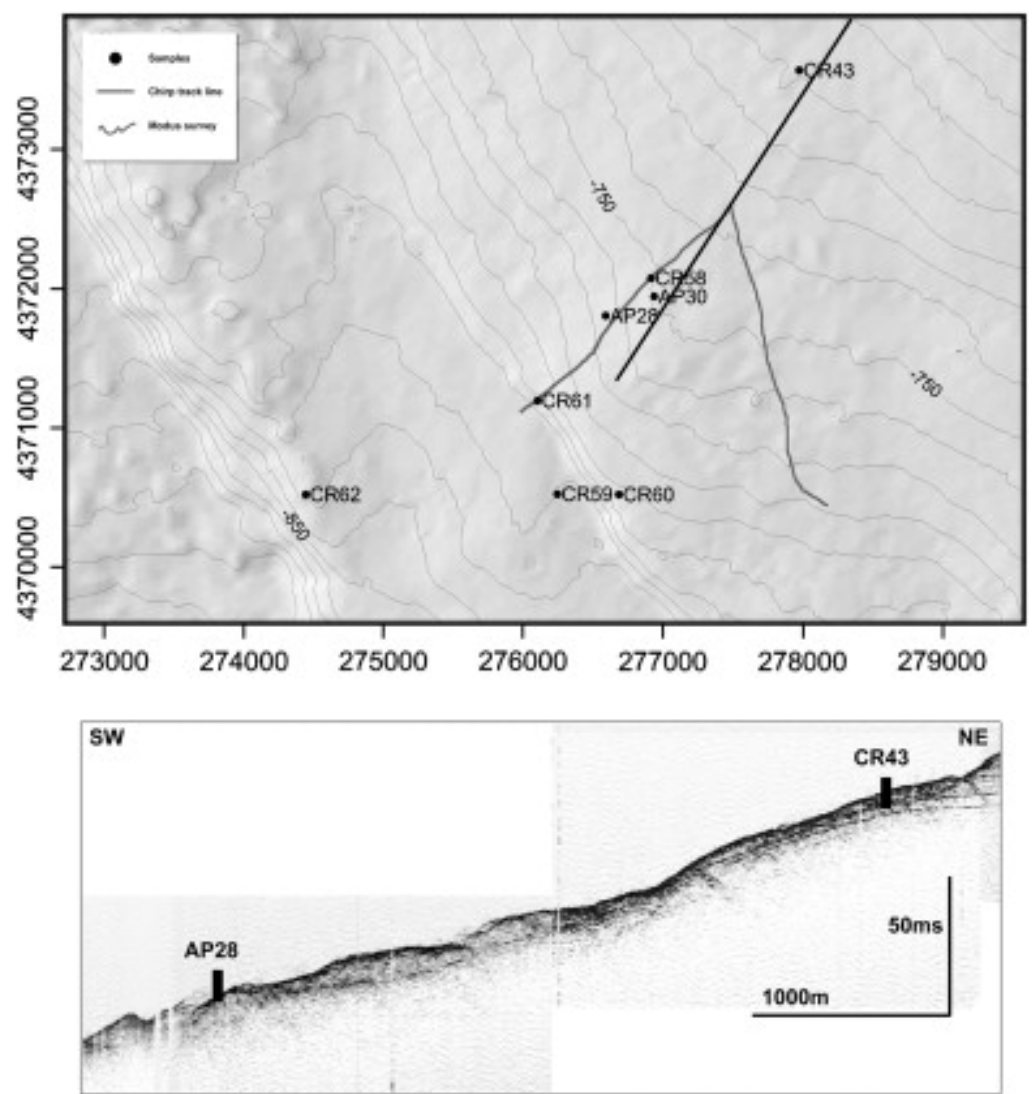

Fig. 7. (a) Map of MS01 area, with sampling location, track of the MODUS visual survey (Vertino et al., 2010) and track of chirp line shown in b; (b) chirp profile through MS01 area, crossing the location of core AP28 and CR43.

Within the area surveyed by MODUS, which testified to the presence of common coral colonies, several grabs and one core were collected (Fig. 8), which recorded a variable stratigraphic pattern. Living corals, consisting of solitary Caryophyllia specimens, were only sampled at one station (AP30). They grow on bio-eroded dark-coated colonial coral branches, covered by recent fluid hemipelagic mud, brown in color and rich in bioclasts and lying on grayish stiff silt embedding fresh-looking (neither bio-eroded nor coated) large-sized Lophelia branches. 


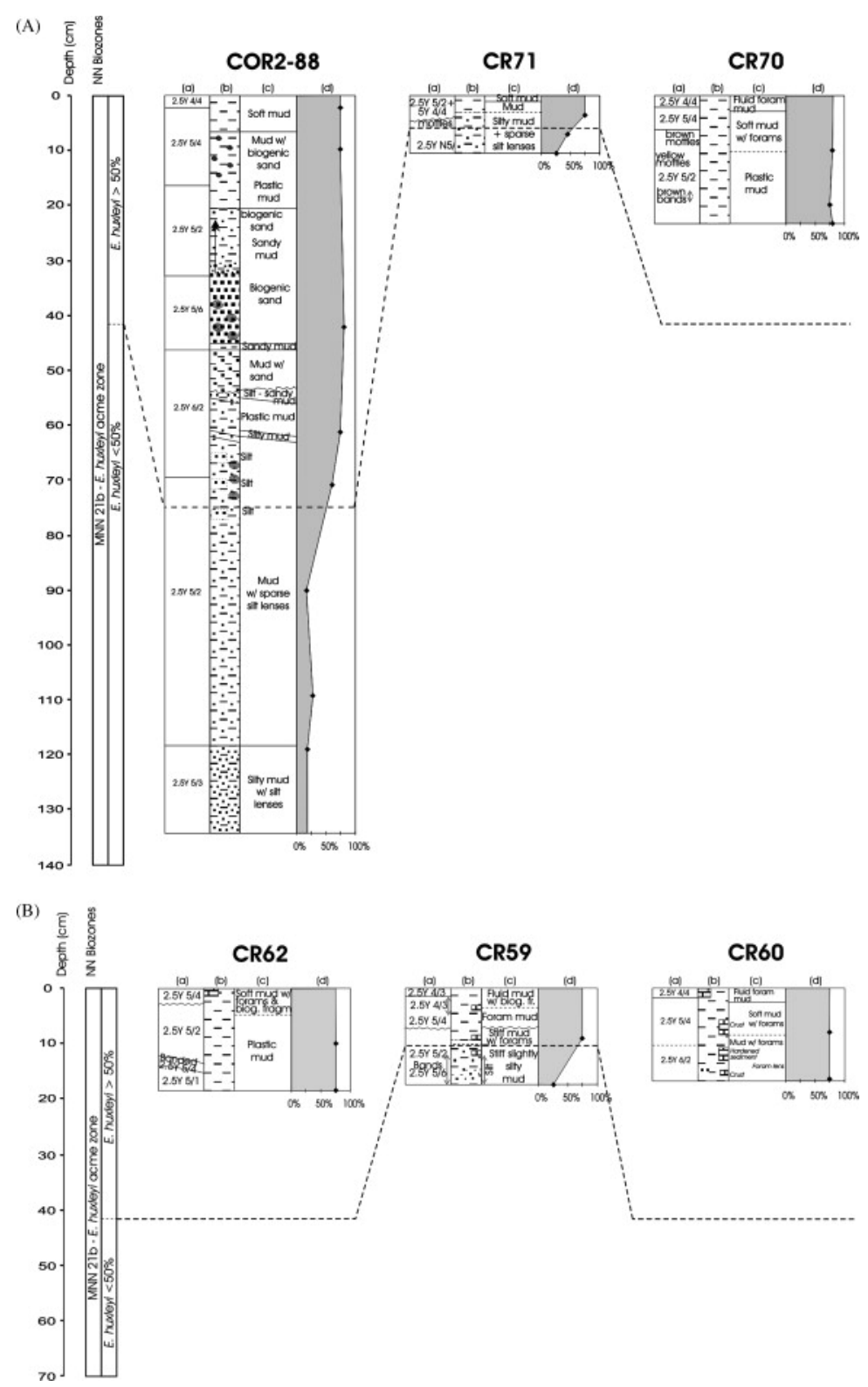

Fig. 8. Lithology of the cores collected within the MS01 area. For each core, four columns are shown, displaying (a) colors, (b) graphic lithology, (c) sediment characterization, (d) relative abundance of E. huxleyi. See Fig. 6 for legend.

The most common stratigraphy recovered by mini-cores (grab samples, upper $\sim 24 \mathrm{~cm}$ ) consists of an upper layer of about $10 \mathrm{~cm}$ of light olive brown foraminifer-rich hemipelagic mud, which passes to grayish brown or light gray stiff hemipelagic mud (CR58, CR59) or stiff plastic hemipelagic mud (CR61, CR62), with a sharp transition. At CR60, both color and lithology exhibit no significant change with depth. Abundant $\mathrm{mm}$ - to $\mathrm{cm}$-thick black crusts and nodules are always present at the surface, while light brownish gray cm-thick hard crusts $($ CR59, 60, 61) and/or hardened mud clasts (CR60) can be present throughout the section.

All samples belong to the upper part of the E. huxleyi acme zone, excluding the base of CR59, which is probably more close to its basal part. U/Th dating of the large-sized Lophelia branches recovered at the base (about $10 \mathrm{~cm}$ ) of AP30, gave an age of $13.96 \pm 0.18 \mathrm{ky}$ B.P.

Most of the cores contain a significant fraction of reworked specimens and abundant fine lithogenic particles, which always tend to increase in abundance in the lower part of the sedimentary succession. An exception is given by core CR60, which contains very low concentrations of lithogenic particles but a high abundance of fine carbonate particles, probably of local origin. 
A very different stratigraphy is recorded, in the same area, by gravity-core AP 28 . The core consists of $110 \mathrm{~cm}$ of hemipelagic silt, with alternating more or less clayely intervals, and frequent coarser silt lenses, showing fine lamination throughout the sequence, interrupted by dm-thick massive intervals (current structures vs. massive pelagic turbidites). Only the upper $5 \mathrm{~cm}$ of the core are oxidized, light olive brown in color, and belong to the upper part of the E. huxleyi acme zone, while the rest of the sediment is reduced, gray in color and can be placed within the lower part of this zone, although not too close to its base (E. huxleyi values of $20-50 \%$ of the total assemblage). Reworked specimens, as well as fine lithogenic particles, are abundant all over the core, excluding the upper $5 \mathrm{~cm}$.

The elongated morphological high, extended in NW-SE direction to the NW of the former area (Fig. 1), was investigated by two grabs, collected at slightly different depths on top of the elevated structure. CR70 contains olive to grayish brown hemipelagic mud, belonging to the upper part of the E. huxleyi zone, with no significant abundance of reworked specimens nor of a lithogenic fraction. CR71 consists of a thin $(5-7 \mathrm{~cm})$ layer of olive brown hemipelagic mud underlain by gray stiff plastic mud, with black reduction spots and containing sparse silt lenses that increase with depth. E. huxleyi is dominant in the upper part of the core but rapidly decreases in abundance, so that the base of the core falls within the lower part of the E. huxleyi acme zone (depositional or erosional lag). Reworked specimens and the concentration of fine lithogenic particles are higher within the gray, more silty interval.

Core CR43 was collected to the NE of the area, along the slope characterized by discontinuous accumulation of sediment slumps and erosion (Fig. 7b). It consists of hemipelagic mud, which is soft and bioturbated in the upper $3 \mathrm{~cm}$, then becomes progressively more silty from $7 \mathrm{~cm}$ downwards, silt-rich from 52 to $70 \mathrm{~cm}$. There are distinct thin coarser layers at 14 and $28 \mathrm{~cm}$. No laminations are visible along the section, excluding the two thin coarser layers. The sediment is oxidized, light olive brown in color in the upper part, then gray, with black reduction spots, which become abundant from $32 \mathrm{~cm}$ downwards. The oxidation front, located around $7 \mathrm{~cm}$, is sharp and irregular in shape.

The whole core belongs to the E. huxleyi acme zone. E. huxleyi is clearly dominant from top to 30 $\mathrm{cm}$ depth, then starts decreasing downwards, ranging variably from $30 \%$ to $60 \%$ mainly due to the fluctuation in abundance of small Gephyrocapsa. Reworking is scarce to absent in the upper $10 \mathrm{~cm}$, then becomes significant, although not major; lithogenic particles are always an important component of the fine fraction. Given the depositional environment, the observed trend of $\mathrm{E}$. huxleyi relative abundance variation also could be related to the mobilization of sediments of slightly different ages within the upper Pleistocene from the elevated area above.

The deepest core recovered in proximity to this area, COR2-88 (Fig. 1), was collected close to the base of a fault scarp at $1147 \mathrm{~m}$ depth, SW of the MS01 area. The core recovered a stratigraphic sequence $(134 \mathrm{~cm})$ mainly constituted by hemipelagic clayey silt, characterized by the occurrence of re-sedimented coarser layers. As well-evidenced from the radiographic image of the core (not shown), sand to fine gravel-sized biogenic fragments are abundant from 20 to $54 \mathrm{~cm}$ and appear to be organized in distinct mud-supported or grain-supported layers, showing a sharp, often erosive base. Microscopic observations of such layers in the $>63-\mu \mathrm{m}$ fraction revealed abundant fragments of cemented silt, some of which include planktonic foraminifera, partly broken and sometimes colonized by serpulids and bryozoans, plus a slightly to well-diversified benthic fauna consisting of bivalves (mostly anomiids and pectinids), benthic foraminifera and subordinate colonial corals, echinoid and octocorallia fragments, ostracods, bryozoans, serpulids, gastropods and scaphopods. 
All these evidences indicate proximity to an area characterized by the presence of coral colonies or coral rubble.

Below $54 \mathrm{~cm}$, the core consists of plastic mud, with no visible sedimentary structures, containing small silt lenses. The coarser $(>63 \mu \mathrm{m})$ fraction is mostly biogenic (mollusk fragments, ostracods, scafopods and rare serpulids and bryozoans) down to $68 \mathrm{~cm}$; below this level lithogenic components become dominant both in the coarse and fine fractions, and the faunal assemblage is generally depleted, although sparse mm-sized bioclasts are present (mostly Lophelia fragments). These variations also coincide with a sharp color change (from light olive gray to olive gray).

The lowest part of the core $(87.5 \mathrm{~cm}$ to the bottom) is made of gray stiff sandy-clayey silt, with very small coarser lenses. Here the lithogenic component is even more abundant ( $>90 \%)$ and the faunal content is scarce.

Calcareous nannofossil biostratigraphy indicates a sharp transition around $69 \mathrm{~cm}$, separating a recent upper layer (E. huxleyi $>70 \%$ ) from a lower sediment sequence, located closer to the base of the E. huxleyi acme zone (E. huxleyi concentration around 20-30\%).

The whole area presents a complex sedimentation (deposition and lag) pattern, with strong lateral variability on a small scale. A tentative complete sediment sequence can be reconstructed for the MS01 site based on the recovered cores and includes, from modern to older intervals:

recent olive brown hemipelagic mud (top of most cores) - upper E. huxleyi acme zone

-

sub-recent light olive brown to grayish brown slightly silty clays (CR61, CR62), containing hard crusts (CR58), or gray massive silty clays (upper CR43) - E. huxleyi $\sim 50 \%$

alternating gray silty clays and clayey silts, with distinct coarser layers but no evident lamination (CR43) - E. huxleyi 30-50\%

gray to grayish brown clayey silt, with coarser lenses, massive (CR59, CR71, lower CR43) or laminated (AP28) - lower E. huxleyi acme zone.

COR2-88, located at higher depth and at the base of a pronounced fault scarp, documents a similar sequence in the lower part, with massive silty clay to clayey silt, followed by frequent layers of coarse material, clearly displaced from shallower depth and possibly channeled along the fault scarp.

The abundance of exposed dark-coated nodules at the sediment top in most cores suggests a prolonged exposure at the surface, possibly due to the influence of currents, and/or re-deposition of dark-coated fragments, which represent a very common element in surrounding elevated areas (relatively old coral colonies, exposed at the surface). Surface sediments are fine-grained, with welldiversified planktonic assemblages, typical of present-day sedimentation. They are possibly related to the combined action of hemipelagic sedimentation and re-deposition by bottom currents, which in this area and at this depth can reach up to $0.2 \mathrm{~m} / \mathrm{s}$ (Budillon et al., 2010). Turbidite deposits, characterized by evident laminations and/or by the presence of distinct coarser layers, can be locally identified only at the subsurface (CR43, AP28). They correspond to older time intervals (lower E. huxleyi acme zone) and are separated from the uppermost recent layers by a non-depositional or erosional lag.

3.5. MS08 area - elongated promontory, with steep West and gentle East slope, strongly eroded 
This area is located on a broad "promontory" (Fig. 9a), extending on a SE direction towards higher depths and related to the formation of anticline structures (Savini and Corselli, 2010). Shallow seismic profiles revealed strong asymmetry in the depositional pattern on this elevated structure (Fig. 9b). In fact the eastern side of this structure is characterized by a large-scale erosional feature, developed on apparently undisturbed layers, while the western side shows a steep and irregular topography, with abundant slumping deposits. Sediment samples were collected close to the top of the promontory, where MODUS survey had showed a widespread occurrence of coral colonies. Although very close to each other, all cores revealed a different stratigraphy (Fig. 10): CR40 (13 $\mathrm{cm}$ ) is constituted by hemipelagic mud, passing from oxidized, light olive to grayish brown in color $(8-10 \mathrm{~cm})$, to reduced, gray in color, through an irregular oxidation front. The whole section is in the upper part of the E. huxleyi zone, has a strong contribution of reworked nannofossil species and contains abundant fine lithogenic particles. In contrast, the hemipelagic mud sequence of core CR38 $(28.5 \mathrm{~cm})$ contains a strong sandy fraction, constituted by coral and mollusk fragments, while the lithogenic contribution is scarce. The whole core is oxidized, light to dark brown in color. It all belongs to the upper part of the E. huxleyi zone, showing little reworking.
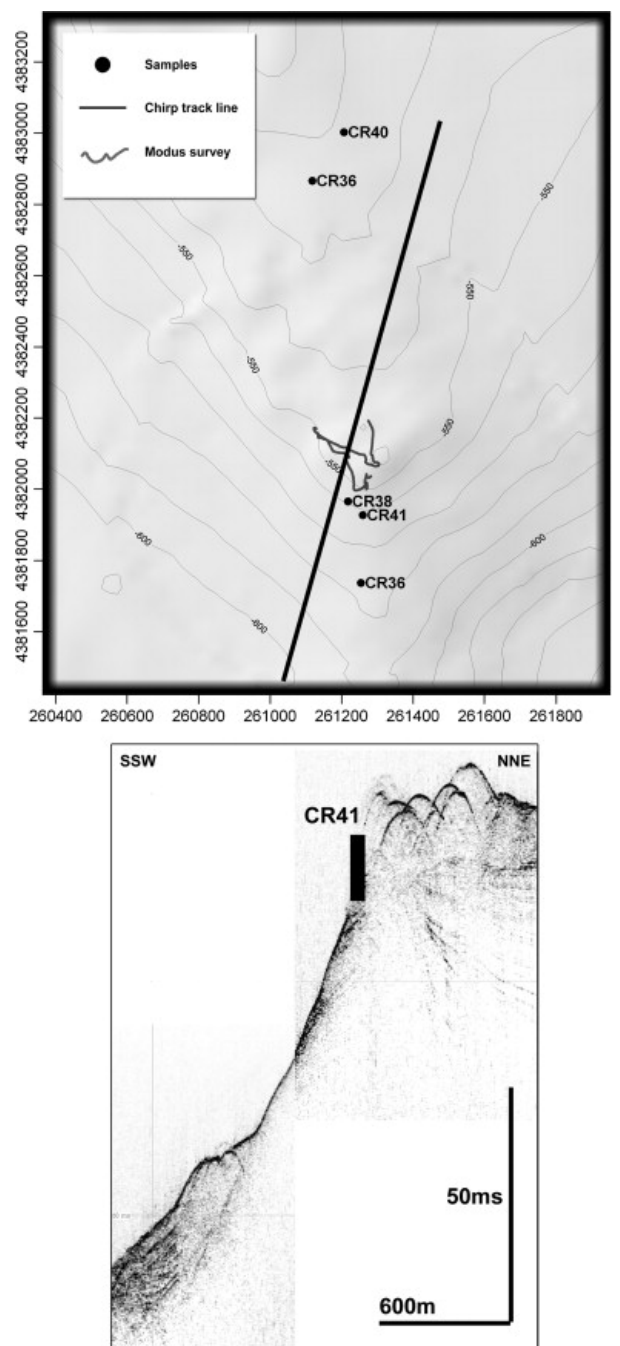

Fig. 9. Map of MS08 area, with sampling location, track of the MODUS visual survey and track of chirp line shown in b; b, chirp profile through MS08 area, close to the location of core CR41. 


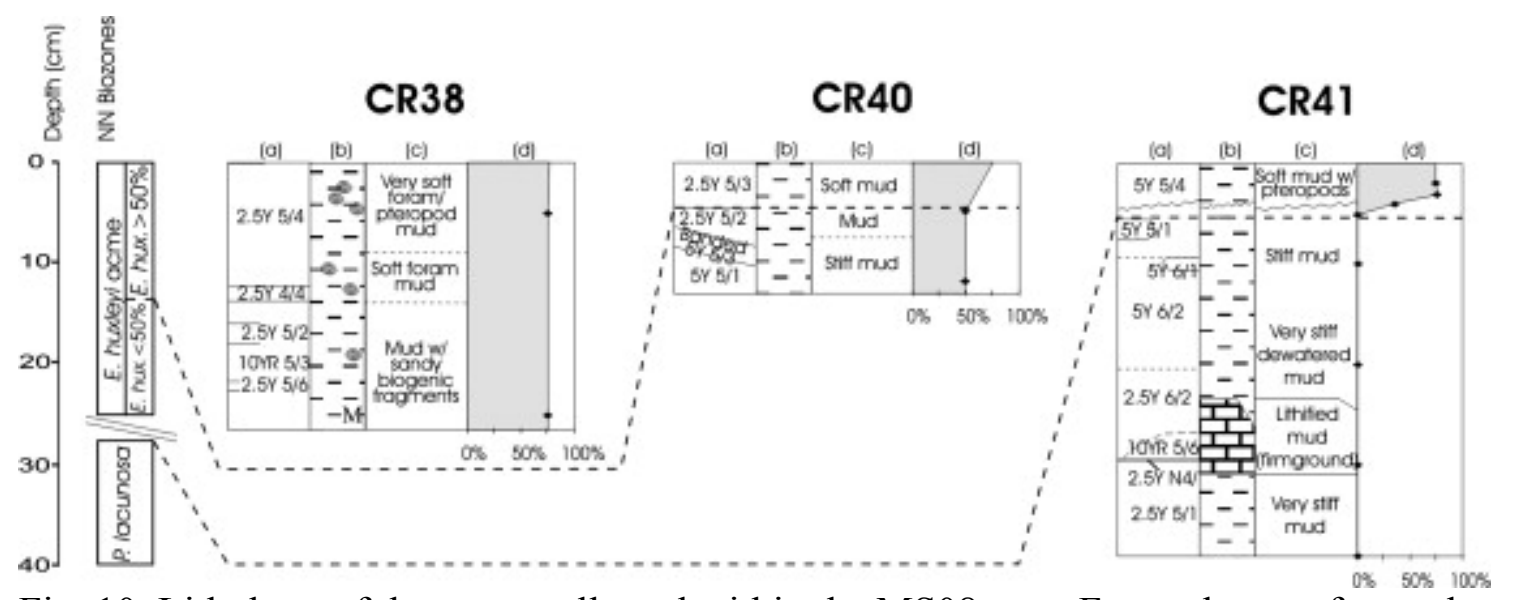

Fig. 10. Lithology of the cores collected within the MS08 area. For each core, four columns are shown, displaying (a) colors, (b) graphic lithology, (c) sediment characterization, (d) relative abundance of E. huxleyi. See Fig. 6 for legend.

CR41, positioned on the right side of the promontory, presents a strong stratigraphic gap: the upper $5 \mathrm{~cm}$ of the core, made of light olive brown soft mud, lay on an erosional surface. Below this, the core is constituted by stiff to very stiff mud, gradually dewatered up to a lithified interval (24-32 $\mathrm{cm})$ and then passing again to very stiff mud. The upper part of this interval is oxidized, light olive gray to light brownish gray in color, with sparse gray mottles. The upper part of the lithified sediment has the same color as the sediment above, with abundant yellowish brown mottles. It is separated by a thin black band from the lower part that is reduced, gray in color. The same color characterizes the underlying stiff mud. The hardened sediment appears as an interval undergoing lithification within the sedimentary sequence, more than a firm-ground developed at the sediment surface. In fact the transition to this interval is gradual, from stiff to very stiff and strongly dewatered mud, both above and below the interval itself.

Only the upper $4 \mathrm{~cm}$ of the core belong to the upper part of the E. huxleyi acme zone (E. huxleyi $>75 \%$ ). Mixing occurs at the erosional surface. The rest of the core belongs to the upper part of the Pseudoemiliania lacunosa zone (upper MNN19f of Raffi and Rio, 1979), as characterized by the following index calcareous nannofossil species: very abundant small and medium-sized Gephyrocapsa, presence of P. lacunosa, absence of Gephyrocapsa sp. 3, which only occurs in the lower part of this zone (e.g. Rio et al., 1990). The whole core shows very little reworking and a very low amount of lithogenic particles.

A similar lithology, belonging to the same stratigraphic interval (upper MNN19f), due to the occurrence of the same index species, was collected by a rock-dredge (CR36) in this area (Fig. 9a). The same dredging also collected an interval of stiff mud, light yellowish brown in color. This belongs to the upper part of the small Gephyrocapsa zone (upper MNN19e of Raffi and Rio, 1979), as defined by the occurrence of very abundant small Gephyrocapsa, frequent P. lacunosa, abundant Reticulofaenestra asanoi, which only occurs from the upper part of this biozone to the beginning of the following (e.g. Maiorano et al., 2004), and absence of Gephyrocapsa sp. 3.

Evidence from these samples, coupled with observations from shallow geophysics, testifies to the presence of a widespread erosional feature on this side of the topographic high, leading to the emergence of stiff and/or hardened substrata, constituted by older sediments. Such intervals, cropping out at the bottom-surface, represent a possible suitable substratum for coral growth.

\section{Summary and conclusions}

Previous chronostratigraphic information in this area was only provided by Taviani et al. (2005a), who documented that deep-water corals established on late Pleistocene units and that the Holocene 
is a very thin draping, if any. The present study shows that a very strong lateral variability exists at a small scale in the sedimentary cover of this sector of the Apulian margin. Coral colonies, lying on a hard substratum, represent patches within areas mostly covered by recent soft sediments.

With only one exception (see below), all the recovered sediment sequences are late Pleistocene in age, falling within the last 50-54 ky B.P. (i.e. E. huxleyi acme zone or MNN21b of Rio et al., 1990), confirming previous data of Taviani et al. (2005a). However, there is a variety of sediment types, essentially hemipelagic silty mud with more or less abundant planktonic fauna, with variable contribution of lithogenic silt and/or fine sand, biogenic material of local origin (coral fragments and associated fauna) and sand-grained material from the shelf (shallow fauna). Sediment accumulation varies from site to site and on a small scale, in relation to the depositional environment and the influence of current action. In fact extended mud sequences ( $>2 \mathrm{~m}$ of sediment within the upper E. huxleyi acme zone), brown in color, with recurrent episodes of silt/sand deposition, alternate with more condensed sequences (lower part of the E. huxleyi acme zone is reached within a few $\mathrm{dm}$ ), showing gradual transition from soft (brown) to stiff (gray) mud. The latter sequence is the most common at many sites colonized by corals, testifying to prolonged nondepositional and/or erosive intervals.

Recent soft sediment is present at all investigated sites and can be represented either by a thin ( 5 $\mathrm{cm}$ ) veneer lying on an erosional or non-depositional disconformity (i.e. unconformity or paraconformity) or by more extended successions. It is also found at the coral-colonized sites, often draping part of the hard-ground and sometimes the base of the solitary corals or colonies. Such sedimentation likely results from the interaction of hemipelagic sedimentation and currenttransported sediments, entrapped within the coral framework.

Sites of outcropping older substratum, detected by geophysical analysis (Savini and Corselli, 2010), as a result of broad slope erosion and/or tilting of large blocks, are documented by video survey at most areas (Vertino et al., 2010) and by direct sampling at one site (i.e. cores CR41 and CR38 at MS08), where early to middle Pleistocene units are present at the sub-surface, below a thin draping of recent soft mud. Within such units, the existence of firm-ground is documented, appearing as the result of compaction and dewatering within the sedimentary sequence itself during its diagenetic history. Fragments of such indurated lithologies can be present within younger sediment successions (i.e. CR60 at MS01).

Dark-coated nodules and fragments are a common feature at the sediment surface, particularly in the MS01 area but also at other sites. Their presence suggests prolonged exposure at the surface, in the area itself or in surrounding elevated areas, from which they probably derive.

Recovery of living and dead coral fragments within the sediment successions or exposed at the seafloor allows to draw a synthesis of coral colonization in the area, through accurate dating of selected samples.

At MS06 site, recovery of a large slab of hard-ground (COR2-101) showing a condensed stratigraphy permits us to summarize the early and subsequent phases of coral colonization by the following: (a) deposition of a glacial Pleistocene muddy unit whose minimum age is represented by P. peslutrae, dated at AMS14C 26,350 \pm 170 y B.P.; (b) onset of strong bottom currents, which cause bivalve orientation and sediment winnowing; (c) a somewhat prolonged non-depositional history causing progressive induration of the sediment exposed to seawater, eventually turning the sediment into firm-ground; (d) first coral colonization of the firm-ground by Caryophyllia dated at AMS14C $10,760 \pm 50$ y B.P. (12.1 \pm 0.2 cal ky B.P.); (e) continuing non-deposition history, with dark coating of 
Caryophyllia corals; (f) second (modern) phase of colonization by Madrepora dated at $2975 \pm 30 \mathrm{y}$ B.P. (2.7 \pm 0.06 cal ky B.P.).

Again at this site, one grab sample (AP01) testifies a former colonization by Lophelia, U/Th dated at $13.96 \pm 0.18$ ky B.P., followed by Madrepora colonies and some solitary corals, some of which still alive.

Within the MS04 area, one core (AP20) recovered abundant coral debris, with variable composition along the sediment succession, documenting the history of more recent deep-coral colonization of the surrounding area. The temporal succession of the coral species and morphotypes seems to reflect the climatic history of the area at the transition from the last glacial to the present interglacial period. Small fragments of thin trumpet-like Lophelia (cooler Pleistocene, AMS14C 13.1 $\pm 0.20 \mathrm{ky}$ B.P.) are followed by large fragments of thick-walled Lophelia (cool Pleistocene) and subsequent Madrepora (warm Holocene). Fresh debris is often accompanied by dark-coated fragments, especially in the upper part of the sequence. Such coating suggests prolonged exposure of the colonies and/or of the fragments, which possibly constitute the hard substratum for subsequent coral development.

\section{Acknowledgments}

This study benefited of funding and ship-time through various national (FIRB "APLABES") and international (ESF Euromargins "Moundforce"; EU "Hermes") programmes. We are grateful to Captains, Crew and Colleagues onboard R.V. Universitatis during APLABES cruises (2003-2005) and R.V. Urania during cruises CORAL (2002) and CORSARO (2006). Special thanks are due to Gabriele Marozzi, Enver Lipparini, Lorenzo Angeletti, Alfio Viola and Michele Vagliasindi for post-cruise technical work. Maria Triantaphyllou is kindly acknowledged for useful comments for the improvement of the manuscript. The present article is a contribution to APLABES, Moundforce, Hermes and Hermione programmes and is ISMAR-Bologna scientific contribution no. 1645 and Catania paleoecological Research Group contribution no. 345.

\section{References}

Budillon et al., 2010

G. Budillon, N. Lo Bue, G. Siena, G. Spezie

Hydrographic characteristics of water masses in the northern Ionian Sea

Deep-Sea Research II, 57 (5-6) (2010), pp. 441-457

Castradori, 1993

D. Castradori

Calcareous nannofossil biostratigraphy and biochronology in eastern Mediterranean deep-sea cores Rivista Italiana di Paleontologia e Stratigrafia, 99 (1993), pp. 107-126

Cimerman and Langer, 1991

F. Cimerman, M.R. Langer

Mediterranean Foraminifera

Slovenska Akademija Znanosti In Umetnosti, 30 (2) (1991) 118 pp

Fleitmann et al., 2003

D. Fleitmann, S.J. Burns, M. Mudelsee, U. Neff, J. Kramers, A. Mangini, A. Matter

Holocene forcing of the Indian monsoon recorded in a stalagmite from Southern Oman 
Science, 300 (2003), pp. 1737-1739

Freiwald et al., 2009

A. Freiwald, L. Beuck, A. Rüggeberg, M. Taviani, M70-1 participants R/V Meteor The white coral community in the central Mediterranean revealed by ROV surveys Oceanography, 22 (2009), pp. 58-74

Freiwald et al., 1997

A. Freiwald, R. Henrich, J. Paetzold

Anatomy of a deep-water coralreef mound from Stjernsund, Western Finnmark, Northern Norway

SEPM Special Publication, 56 (1997), pp. 141-162

Freiwald and Schönfeld, 1996

A. Freiwald, J. Schönfeld

Hyrrokkin sarcophaga Cedhagen, 1994 (Foraminifera) in a modern deep-water coral reef mound Marine Micropaleontology, 28 (1996), pp. 199-207

Hemleben et al., 1989

C. Hemleben, M. Spindler, O.R. Anderson

Modern Planktonic Foraminifera

Springer-Verlag, Berlin (1989) 363 pp

Hughen et al., 2004

K.A. Hughen, M.G.L. Baillie, E. Bard, A. Bayliss, J.W. Beck, C. Bertrand, P.G. Blackwell, C.E. Buck, G. Burr, K.B. Cutler, P.E. Damon, R.L. Edwards, R.G. Fairbanks, M. Friedrich, T.P.

Guilderson, B. Kromer, F.G. McCormac, S. Manning, C. Bronk Ramsey, P.J. Reimer, R.W.

Reimer, S. Remmele, J.R. Southon, M. Stuiver, S. Talamo, F.W. Taylor, J. van der Plicht, C.E.

Weyhenmeyer

Marine04 marine radiocarbon age calibration, 0-26 cal kyr BP

Radiocarbon, 46 (2004), pp. 1059-1086

Kennett and Srinivasan, 1983

J.P. Kennett, M.S. Srinivasan

Neogene Planktonic Foraminifera

Hutchinson Ross Publishing Company, Stroudsburg (1983) 265 pp

Lourens, 2004

Lourens, L.J., 2004. Revised tuning of Ocean Drilling Program Site 964 and KC01B

(Mediterranean) and implications for the delta O-18, tephra, calcareous nannofossil, and geomagnetic reversal chronologies of the past 1.1 Myr. Paleoceanography 19 (3), article no. PA3010.

Ludwig, 1999 
Ludwig, K.R., 1999. Isoplot/Ex 2.06, a geochronological toolkit for Microsoft Excel. Berkeley Geochronology Center Special Publication 1a, pp. 1-49.

Maiorano et al., 2004

P. Maiorano, M. Marino, E. Di Stefano, N. Ciaranfi

Calcareous nannofossil events in the lower-middle Pleistocene transition at the Montalbano Jonico section and ODP site 964: calibration with isotope and sapropel stratigraphy

Rivista Italiana di Paleontologia e stratigrafia, 110 (2) (2004), pp. 547-557

Malatesta and Zarlenga, 1986

A. Malatesta, F. Zarlenga

Northern guests in the Pleistocene Mediterranean

Geologica Romana, 25 (1986), pp. 91-154

Mastrototaro et al., 2001

Mastrototaro, F., Tursi, A., Matarrese, A., 2001. Un mare di coralli in Mar Ionio. $32^{\circ}$ Congr. SIBM, Numana-Riviera del Conero 4-9/6/2001 Abstracts: 112.

Mercone et al., 2000

D. Mercone, J. Thomson, I.W. Croudace

Duration of S1, the most recent sapropel in the eastern Mediterranean Sea, as indicated by accelerator mass spectrometry radiocarbon and geochemical evidence

Paleoceanography, 15 (3) (2000), pp. 336-347

Murray, 2006

J.W. Murray

Ecology and Applications of Benthic Foraminifera

Cambridge University Press, Cambridge (2006) 426 pp

Perch-Nielsen, 1985

K. Perch-Nielsen

Cenozoic calcareous nannofossils. Mesozoic calcareous nannofossils

H.M. Bolli, J.B. Saunders, K. Perch-Nielsen (Eds.), Plankton Stratigraphy, Cambridge University Press, Cambridge (1985), pp. 329-538

Pujol and Vergnaud Grazzini, 1995

C. Pujol, C. Vergnaud Grazzini

Distribution patterns of live planktic foraminifers as related to regional hydrography and productive systems of the Mediterranean-Sea

Marine Micropaleontology, 25 (2-3) (1995), pp. 187-217

Raffi and Rio, 1979

I. Raffi, D. Rio

Calcareous nannofossil biostratigraphy of DSDP site 132-leg13 (Thyrrenian Sea-Western

Mediterranean) 
Rivista Italiana di Paleontologia e Stratigrafia, 85 (1979), pp. 127-172

Rio et al., 1990

D. Rio, I. Raffi, G. Villa

Pliocene-Pleistocene calcareous nannofossil distribution patterns in the Western Mediterranean K.A. Kastens, J. Mascle (Eds.) et al., Proceedings of the Ocean Drilling Program Scientific Results, vol. 107College Station, Texas (1990), pp. 513-533

Rosso et al., 2010

A. Rosso, A. Vertino, I. Di Geronimo, R. Sanfilippo, F. Sciuto, R. Di Geronimo, D. Violanti, M. Taviani, A. Tursi, F. Mastrototaro

Hard versus soft-bottom thanatofacies from the Santa Maria di Leuca deep-water coral mound province, Recent Mediterranean

Deep-Sea Research II, 57 (5-6) (2010), pp. 360-379

Savini et al., 2004

Savini, A., Lo Bue, N., Malinverno, E., Corselli, C., Di Geronimo, I., Rosso, A., Tursi, A., 2004. Carbonate mounds on the Apulian continental slope: morphology, distribution and their relation with dead and living deep-water corals. GNGTS - Atti del $23^{\circ}$ Convegno Nazionale.

Savini and Corselli, 2010

A. Savini, C. Corselli

High resolution bathymetry and acoustic geophysical data from Santa Maria di Leuca Cold Water Coral province (Northern Ionian sea - Apulian continental slope)

Deep-Sea Research II, 57 (5-6) (2010), pp. 326-344

Sgarrella and Moncharmont Zei, 1993

F. Sgarrella, M. Moncharmont Zei

Benthic Foraminifera of the Gulf of Naples (Italy) systematics and autoecology

Bollettino della Società Paleontologica Italiana, 32 (2) (1993), pp. 145-264

View Record in Scopus | Cited By in Scopus (161)

Sprovieri et al., 1998

R. Sprovieri, E. Di Stefano, M. Howell, T. Sakamoto, A. Di Stefano, M. Marino

Integrated calcareous plankton biostratigraphy and ciclostratigraphy at Site 964

A.H.F. Robertson, K.C. Emeis, C. Richter, A. Camerlenghi (Eds.), Proceedings of the Ocean

Drilling Program, Scientific Results, vol. 160College Station, Texas (1998), pp. 155-165

Taviani et al., 2005a

M. Taviani, A. Remia, C. Corselli, A. Freiwald, E. Malinverno, F. Mastrototaro, A. Savini, A. Tursi

First geo-marine survey of living cold-water in the Ionian Sea (Mediterranean basin)

Facies, 50 (2005), pp. 409-417 http://dx.doi.org/10.1007/s10347-004-0039-0

View Record in Scopus | Full Text via CrossRef | Cited By in Scopus (38)

Taviani et al., 2005b

M. Taviani, A. Freiwald, H. Zibrowius

Deep coral growth in the Mediterranean Sea: an overview 
A. Freiwald, J.M. Roberts (Eds.), Cold-water Corals and Ecosystems, Springer, Berlin (2005), pp. $137-156$

Full Text via CrossRef

Vertino et al., 2010

A. Vertino, A. Savini, A. Rosso, I. Di Geronimo, F. Mastrototaro, R. Sanfilippo, G. Gay, G. Etiope Benthic habitat characterization and distribution from two representative sites of the deep-water SML Coral Mound Province (Mediterra- nean)

Deep-Sea Research II, 57 (5-6) (2010), pp. 380-396

Article | PDF (2664 K) | View Record in Scopus | Cited By in Scopus (9) 